\title{
From Inferior to Superior Products: An Inquiry into the Wenzhou Model of Industrial Development in China ${ }^{1}$
}

\author{
Tetsushi Sonobe, \\ Foundation for Advanced Studies on International Development, Tokyo 162-8677, Japan \\ Dinghuan $\mathrm{Hu}$ \\ Institute of Agricultural Economics, Chinese Academy of Agricultural Sciences, \\ Beijing 100081, China \\ Keijiro Otsuka \\ Foundation for Advanced Studies on International Development, Tokyo 162-8677, Japan
}

(May 2004)

Running head: Wenzhou Model of Industrial Development 


\title{
From Inferior to Superior Products: An Inquiry into the Wenzhou Model of Industrial Development in China
}

\begin{abstract}
Although the vitality of small private enterprises as the prime mover of the substantial economic growth in Wenzhou is widely recognized, empirical research investigating the development process of such private enterprises is useful. Based on a survey of enterprises producing low-voltage electric appliances, we find that the entry of a large number of new enterprises producing poor-quality products was followed by the upgrading of product quality and the introduction of new marketing strategies. Hence, we attempt to identify statistically the mechanisms underlying this evolutionary process of industrial development.
\end{abstract}

JEL classification numbers: O12, P23 


\section{Introduction}

China's substantial economic growth in the 1980s is attributable mainly to townshipand village enterprises (TVEs) according to Chen et al. (1992), Jefferson et al. (1996), and Otsuka et al. (1998). However, the private sector emerged as the new engine of Chinese economic growth in the 1990s. The heartland of this private sector growth is Zhejiang Province, particularly in Wenzhou City as Zhang (1989), Nolan (1990), Dong (1990), Wang (1996), Li (1997), Zhang (1999) and Sonobe et al. (2002) attest. Although Wenzhou used to be a poor rural area, it now ranks among the most prosperous cities in China due to its relatively rapid economic growth in the 1980s and its explosive growth in the 1990s. Initially poor farmers began to produce poor-quality consumer goods, e.g., apparel and footwear items, and sold them in major cities throughout China. The label indicating that the product was made in Wenzhou became synonymous with inferior products. With the rise in their income levels in the 1990s, consumers in China became increasingly fastidious about the quality of products. Hence, enterprises in Wenzhou attempted to improve the quality of their products. How these enterprises were able to upgrade their products and overcome their bad reputations to capture the national market is the topic of this paper.

The development strategy pursued in Wenzhou is widely acclaimed, but few empirical inquiries have investigated how small and medium scale enterprises in Wenzhou 
achieved such dramatic industrial growth. We analyze the process of innovation and imitation in the industrial development in Wenzhou by using primary data collected from private enterprises in the low-voltage electric appliance industry. Low-voltage electric appliances refer to products such as switches, wall outlets, and ammeters that are used mainly in houses, apartments, and office buildings. In the planned economy period, these items were rationed and it was difficult to obtain replacements and parts. Before the economic reform in 1978 , this industry began in Wenzhou when a farmer produced simple parts using scraps from the factories of state owned enterprises and sold them illegally to factories and offices in Shanghai. Schumpeter (1912) classifies this activity as a new combination so that this farmer should be considered to be an innovator. In the mid-1980s, when a number of enterprises produced and marketed low-quality products despite increasing complaints from their customers, a few enterprises began to improve the quality of their products. One enterprise actually introduced new marketing strategies, such as the establishment of a brand name and the development of a network of own sales throughout China, to overcome the bad reputation of Wenzhou as the homeland of inferior products. The introduction of these new strategies constitutes another innovation, which had a pervasive impact on the growth of the industry because it stimulated imitation by many other enterprises. 
Recently, the evolutionary process of innovation and imitation in the economic literature has attracted much attention, e.g., Filson (2002), Gort and Klepper (1982), Jovanovic and MacDonald (1994a and 1994b), Klepper (1996 and 2002), and Klepper and Simons (2000). However, few empirical studies are found in less developed economies. In this paper, we investigate the improvement of product quality, the marketing strategies for overcoming the bad reputation, and the diffusion through imitation by followers in Wenzhou. We also explore the consequences of this innovation and imitation for the growth performance of the industry to understand the essence of the Wenzhou model of industrial development.

The paper is organized as follows. Section 2 contains a brief conceptual framework. After the pattern of economic growth in Wenzhou is described, Section 3 provides details of the history of the industry, especially the process of improvements in product quality. Section 4 formulates the hypotheses and specifies the equations for empirical testing in Section 5. Finally, we summarize our major findings and discuss implications for future studies in Section 6.

\section{Conceptual Framework}

Until the mid-1980s, the quality of manufactured products was not a major concern 
of Chinese consumers because most goods were in short supply. In the planned economy, planners had little interest in the quality of building materials and components as long as the structures built did not topple; hence, builders used cheap materials and components, including low-voltage electric appliances. As the transition from a planned economy to a market economy proceeded and as the income level of consumers rose, poor quality products became increasingly difficult to sell and it became profitable to improve product quality. According to our interviews, an increasing number of low-voltage electric appliance enterprises in Wenzhou began improving the quality of their products in the late 1980s. Subsequently, enterprises introduced a mass production system to meet the rapidly growing demand for their products due to the booming construction business and the rapid electrification in poor rural villages in the 1990s.

According to the literature concerning the effects of imperfect information on product quality pioneered by Akerlof (1970), an enterprise's effort to improve quality may be fruitless due to adverse selection if the products having improved quality are intermingled with poor-quality products of other enterprises. This literature suggests several strategies to avoid this problem, including the establishment of brand names, direct transactions with customers, and the use of sales agencies that deal only in the enterprise's products. If the brand name is virtually unknown to consumers, the producer who has just improved 
product quality may not be able to command the high prices associated with high quality items until his reputation is established. Shapiro (1983) assumes that the price $p$ of a product is an increasing function of the level of quality $\theta_{P}$ perceived by consumers whereas production $\operatorname{cost} C$ is an increasing function of both actual quality $\theta_{A}$ and output $Q$. Hence, profit is given by $\pi=p\left(\theta_{P}\right) Q-C\left(Q, \theta_{A}\right)$. Immediately after quality improvement, perceived quality $\theta_{P}$ remains low whereas production cost has increased with the increase in the actual quality $\theta_{A}$ so that the profit margin decreases. Shapiro (1983) demonstrates that the optimal policy is to keep selling the improved product with thin profit margins for a certain period of time, which can be interpreted as an investment in reputation. Klein and Leffler (1981) show that high profit margins of enterprises with good reputations encourage them to maintain their reputations for the high quality of products.

We adopt the following conceptual framework to investigate quality improvement in the low-voltage electric appliance industry in Wenzhou. Suppose that the products of all enterprises are equally poor initially, but that some enterprises succeed in improving product quality. For these forerunners, a perception gap between $\theta_{P}$ and $\theta_{A}$ emerges leading to low profit margins even if these enterprises introduce signaling devices such as brand names and own retail networks. As a result, sales volume does not increase in the short run in spite of the improved product quality. However, consumers who purchase the 
products of these enterprises revise their perceptions if the high quality is maintained and this information may also be communicated to other potential buyers. The rapidity with which perception gaps are narrowed depends on sales volume, which will in turn depend on the price of the product. As Shapiro (1983) indicates, quality-improving enterprises may reduce the price, and profit margins, intentionally to build their reputations for quality. As the perception gap narrows, these enterprises earn high profits and begin to grow.

Observing the success of such enterprises, an increasing number of other enterprises follow suit by imitating both the high quality products and the marketing strategies of the leading enterprises. These followers may also imitate the production processes of the leaders to meet the increasing demand for high quality products. Other enterprises that do not imitate the products or marketing strategies of the leaders are left behind. However, since the range of the Chinese markets served by producers of electric components is vast, some enterprises may specialize intentionally in the low-quality segment of the market and target rural households with very low incomes. Thus, our conceptual framework suggests that three types of enterprises, namely, leaders, followers, and laggards, will arise.

Efforts to improve product quality represent partly a response to the declining profitability of producing simple, low-quality products and partly a response to the increasing demand of consumers for high-quality products associated with income growth. 
Although statistical evidence on quality improvements of low-voltage electric appliances in the entire Chinese market is difficult to obtain, our informal interviews with enterprise managers in Wenzhou clearly indicate that competition on quality has intensified since the late 1980s. However, the growing demand for high-quality products is exogenous to the enterprises in Wenzhou because it is determined by the rate of economic growth of the entire Chinese economy. Although the demand for high-quality products would have grown gradually with income growth, quality competition began suddenly after the profitability of producing low quality products declined in the early 1990s. Hence, internal economic forces stimulated directly the improvement of product quality.

We conjecture that the managers in the leading enterprises are more educated than those in the other enterprises and that their prior experience in marketing influences their marketing strategy by the leading enterprises. Such a link between innovation and experience is suggested by both historical evidence and recent case studies of industrial development. Landes (1969) argues that the internal contradictions of the putting-out system in the proto-industrialization in England in the seventeenth century, such as the embezzlement of cloth and other material by domestic weavers, were overcome by merchants through the introduction of the factory production system because their experiences in selling and manufacturing alerted them to the possibility of this new 
profitable production system. Recent case studies of garment clusters in Hiroshima Prefecture in Japan after World War II and in Zhejiang Province in China for the last two decades report that new marketing and production systems were introduced to these clusters by former local merchants with relatively high education when inferior products were replaced with superior products (Sonobe et al., 2002 and Yamamura et al., 2003). In a case study of the machine tool industry in Taiwan, Sonobe et al. (2003) reports that the new methods of production and marketing of numerically controlled machines were first introduced by two new enterprises with highly educated managers and that these new methods were imitated quickly by the experienced manufacturers of machine tools. In the following section, we characterize the innovators and imitators in Wenzhou based on their educational and occupational backgrounds.

\section{The Process of Economic Development in Wenzhou}

When the economic reform started in 1978, Wenzhou was densely populated but endowed with little arable land. Poor farmers peddled miscellaneous low-quality, hand-made goods, such as leather goods, apparel, and footwear, to major cities. Within Wenzhou, few state-owned enterprises were set up because Wenzhou is close to Taiwan and the financially weak local governments could not afford to establish TVEs. However, in the early 1980s, a large number of small-scale red-cap enterprises emerged, which were 
essentially private but disguised themselves as TVEs. As Nolan (1990) asserts, private enterprises were important in the non-farm sector in poor areas with weak non-farm economies.

The local governments in Wenzhou did not simply permit free economic activities passively; they facilitated them by constructing several local marketplaces. According to our interviews with the managers of long-established enterprises producing low-voltage electric appliances, the establishment of the marketplace for various metal products in Yueqing city, which is a lower-level city within Wenzhou city, reduced drastically the difficulties in procuring raw materials and finding buyers for their products. In the marketplace, producers learn the ideas and designs of other producers and obtain information from outside traders on what products are selling in large cities. The drastic reduction in search costs and the spillovers of valuable market information not only helped incumbents but also attracted new entrants, who were farmers, factory workers, and traders. Thus, the entry of new enterprises increased significantly after the construction of the marketplace in the early 1980s. As a result, a cluster of enterprises producing similar products was formed in Yueqing. Similar development processes took place in other cities within Wenzhou specializing in other products, such as garments, footwear, and cigarette lighters. Thus, Dong (1990), Wang (1996), and Li (1997) argue that, although the major 
characteristic of the Wenzhou model of development is the growth of private household enterprises, the role of specialized markets in facilitating transactions of parts and final products is no less important. $^{2}$

Friedman (2003) argues that to interpret accurately what is happening in China today requires a knowledge of history, particularly a history of cities. Wenzhou has a long tradition of handicrafts and commerce beginning in the Sung period, even though it was not as prosperous as Ningbo, a center of long-distance as well as foreign trade, from which it is separated by a chain of high mountains (Shiba, 1968, 1977; Skinner, 1977). Because of this tradition, this city was endowed with substantial human capital in the form of latent mercantile skills when the reform began and, consequently, it had strong potential for growth. Indeed, this tradition led to active outmigration of Wenzhou people during the reform period, which has contributed to the formation of Wenzhou markets in various large Chinese cities and commercial networks between Wenzhou and those cities, including Beijing (Zhang, 2001). Thus, the Wenzhou model of development, which depends on a network of Wenzhou traders working throughout China, may not be replicable. Nonetheless, rural-urban information and marketing networks created through migration play a key role in the development of rural industries in other parts of China (Murphy, 2002) and also in other East Asian countries (Otsuka, 1998). 
Figure 1 displays the trends of GDP per capita in China, Wenzhou, and Yueqing beginning in 1978. Although GDP per capita in Yueqing and Wenzhou was 60 percent of the Chinese average in 1978, the three became equal in 1992 and GDP per capita in Yueqing and Wenzhou became twice the Chinese average by 1998. Moreover, economic growth in Yueqing and Wenzhou accelerated in the 1990s. Hence, economic growth in Wenzhou may be characterized as relatively rapid in the 1980s and explosive in the 1990s. To investigate the factors behind this growth and its acceleration, we turn to the results of our enterprise survey.

In May 2000, we conducted informal interviews with managers of the two largest enterprises producing low-voltage electric appliances and nine other enterprises producing garments, footwear, and cigarette lighters in Wenzhou. ${ }^{3}$ After this survey, we decided to focus on the low-voltage electric appliance industry and conducted a second wave of personal interviews with eight enterprise managers, including the initiator of this industry, in December 2000. Based on these interviews, we designed questionnaires, pretested them, and conducted a formal survey of 117 enterprises producing finished products and 90 enterprises producing parts in Yueqing city from May to December 2001. In this paper, we analyze the data for enterprises producing finished products and leave the analysis of parts suppliers to future study. ${ }^{4}$ We obtained data on production and costs in 1990, 1995, 
and 2000, as well as various characteristics of the enterprises, their founders, and their current managers. We eliminated five enterprises from the analysis because their production and cost data were either incomplete or highly suspicious. Thus, the sample consists of 112 enterprises, all of which were active at the time of our survey.

Table 1 displays the number of sample enterprises, the average years of schooling of the founders, and the percentage composition of their occupational backgrounds at the time of their entry into the industry. The industry began in 1973 and the number of new entrants increased dramatically in the early 1980s when the first marketplace was constructed. The years of schooling of the founders increased gradually along with the increase in the average education level in Wenzhou. However, the occupational backgrounds of the entrants changed drastically. The proportion of farmers was high among the early entrants and that of factory workers was high in the early 1980s, suggesting that prior knowledge of marketing and engineering was not an entry requirement in the early stage of development. ${ }^{5}$ In the later periods, the proportion of these occupations declined as the majority of new entrants were salesmen and traders, which is characteristic of merchant-led industrial development, in which merchants are entrepreneurs. ${ }^{6}$

Table 2 reports the changes in the number of sample enterprises and the average size 
of production. In the late 1990s, enterprise groups were formed through mergers as was common in many other industries in China. ${ }^{7}$ Of the 112 sample enterprises, 28 enterprises were registered as groups by 2000 and the largest group had about 70 subsidiaries. Reflecting the formation of groups, an increasing number of sample enterprises became subsidiaries; the number of subsidiaries in the sample was zero in 1990, six in 1995, and 39 in $2000 .^{8}$ At the same time, a large number of enterprises left the industry in the late 1990s because their management was too inefficient to be reformed. As a result, the number of independent enterprises in the sample, excluding subsidiaries, increased from 66 to 94 in the early 1990 s and decreased to 73 in the late 1990 s.

Most conspicuous in Table 2 is the explosive expansion of the average size of enterprise in the late 1990s, which is in a sharp contrast to its moderate growth during the first half of the 1990s. Moreover, the data on production refer only to the core or parent enterprises in the case of enterprise groups. If the subsidiaries of the sample enterprises were included and the total sizes measured by the sum of real value added, the average size of the sample enterprises in 2000 would be about 1.6 times as large as shown in the table. Thus, the late 1990s is a period of drastic expansion of enterprise size. However, enterprise managers report no significant change in production technology toward mass production. Hence, this rapid expansion and group formation must be attributable to 
factors other than technical change. Table 3 classifies the sample enterprises into five categories according to the timing of the formation of an enterprise group. An enterprise group consists of a parent enterprise and subsidiaries that produce finished goods under the same brand name, whether or not they are registered officially as an enterprise group. The timing of group formation is determined by whether the production of subsidiaries was zero or positive in the three sample years, i.e., 1990, 1995, and 2000. ${ }^{9}$ Enterprises that formed groups before 1995 were long-established ones, operated by managers with relatively high education.

Since poor-quality products could be sold in the planned economy and due to the thriving new marketplace, many enterprise managers entered the industry with little prior knowledge of manufacturing or marketing. Although specific information on the quality of products is unavailable, consumers bought faulty products and complained that they did not function well. The managers of long-established enterprises report that none of the enterprises had even the simplest instrument for testing their products before shipping. Since the apparel and footwear products made in Wenzhou were notorious for their poor quality, consumers were likely to have a low opinion of electric appliances made in Wenzhou.

The main determinant of the rapid growth of this industry in the 1990s is the 
upgrading of product quality, which began in the mid-1980s when two partners founded an enterprise with the novel idea of shipping only after quality inspection. As Table 4 reports, the number of engineers as a proportion of workers increased steadily in the 1990s. The employment of engineers is important for two reasons; first, engineers can improve the quality of their products and second, they can organize rapidly expanding production needed to meet the increasing demand for products of improved quality. The average number of subcontractors also increased rapidly in the late 1990s. Although parts suppliers existed in the 1980s, their relationship with finished goods producers consisted of mainly arm's length transactions. In the 1990s, the two parties began to build more intimate and longer-term subcontracting relationships. Based on their accumulated experience, these subcontractors were capable of producing high-quality parts.

The introduction of quality inspection drove the upgrading of marketing activities. To avoid intermingling inspected products with defective products, enterprises began to use brand names and developed new marketing channels using their own retail shops and sales agencies, which dealt only in their products. As Table 4 indicates, the importance of these new marketing channels increased throughout the 1990s whereas the marketplace and local traders declined in importance, especially in the late 1990s. By using local sales agencies, even a small enterprise could distribute its products to distant large cities so that the 
proportion of business done by sales agencies increased more rapidly than that of own retail shops during the 1990s. The largest enterprises had as many as 800 sales agencies throughout China by the late 1990s, even though these enterprises put higher priority on the development of own retail networks. The enterprises solve the agency problem associated with sales agencies by using local community ties; almost all of their sales agencies are merchants from Wenzhou who settled in large cities earlier. ${ }^{10}$ Thus, the enterprises in Wenzhou took advantage of the tradition of out-migration to lower the transaction costs associated with the use of sales agencies.

Table 5 shows the increasing proportions of enterprises adopting new marketing strategies beginning in the late 1980s. The increasing use of sales agencies required the establishment of brand names. In addition, a certificate of national standard or international standard, which is granted by the central government body to an individual product if it satisfies the appropriate quality standard, validates the high quality of the product. The first enterprise to adopt new market strategies was also the first to form an enterprise group. In this sense, the enterprise is an innovator, even though it was not the first to begin quality inspection. Consistent with merchant-led industrial development, the manager of this enterprise was a former salesman. New marketing strategies were adopted by five relatively long-established enterprises, which also formed enterprise groups 
in the early 1990s following the lead of the innovator. Among these five enterprises was the first enterprise to introduce quality inspection, so that we consider these five enterprises plus the innovator to be the leaders of the industry. ${ }^{11}$

The leaders formed enterprise groups before other enterprises because the demand for their products increased dramatically with the increase in consumers' recognition of their brand name. While many enterprises were still producing poor quality products, the leaders were selling high quality products under brand names through networks of sales agencies or in their own retail outlets. Moreover, they noticed the effect that their expanded scale of marketing activities had on increasing total sales. To exploit this size effect, the leaders began to form enterprise groups through mergers. A manager of a large group reports that, among small enterprises, the relatively high-performing ones were the first to recognize the importance of size. Hence, these profitable ventures became subsidiaries of larger enterprises early, whereas many other small enterprises resisted mergers at first but eventually became subsidiaries after suffering large losses.

Table 6 classifies the other enterprises into followers, laggards, and converts. Some enterprises introduced original strategies regarding labor management, recruitment and factory operation in addition to quality improvement and marketing. Other enterprises chose to stay in the low-quality segment of the market. However, the majority 
of the enterprises adopted the leaders' strategies, at least partially, and the followers simply imitated the leaders. Converts are defined as enterprises that became subsidiaries of other enterprises by 2000. Both the followers and the laggards were independent enterprises in 2000, but they differ in that the followers formed enterprise groups in the late 1990s whereas the laggards did not have subsidiaries by 2000 . Thus, the classification in this table is identical to that in Table 3 in which enterprises are classified according to the timing of group formation. As Table 3 reports, leaders operate for longer periods and are founded by more-educated managers, which is consistent with the case studies discussed in Section 2.

According to Table 6, except for the innovator, the leaders had a remarkably high proportion of workers that were engineers, especially in 1990. Engineers help improve product quality and upgrade production processes. In 1990, these enterprises had the lowest average profit margin defined as the ratio of operating profit to sales revenue, but improved to record the highest averages in 1995 and 2000. In the early 1990s, the leaders increased their share of sales revenue earned through agencies and in their own retail networks, and increased product variety more rapidly than any other enterprise type. The number of product specifications was increased to attract sales agencies that had to satisfy varied consumer preferences. Although data on the number of product specifications may 
be inaccurate because the method of counting specifications is likely to be different among enterprises, the substantial increase in product variety indicates fierce competition for market share. In the late 1990s, the followers began to increase their share of the new marketing channels and the number of product specifications dramatically.

Figure 2 plots the growth in average enterprise size of the leaders omitting the innovator, the followers, the laggards, and the converts relative to the innovator. Enterprise size is measured by value added, including subsidiaries in the case of enterprise groups. ${ }^{12}$ Interestingly, all enterprises, except for the innovator, were of similar sizes in 1990, despite the fact that the leaders had much higher proportions of workers that were engineers. Due to the efforts of the engineers to improve product quality and upgrade production processes, the leaders grew rapidly in the early 1990s and surpassed the innovator by 1995 .

Thus, it seems clear that a major innovation took place in the low-voltage electric appliance industry in Wenzhou around 1990, which was followed by imitation throughout the 1990s. It is also clear that some imitators were successful, while others were not. In the next section, we will attempt to explore statistically what management strategies were conducive to the successful performance. 


\section{The Empirical Specification}

In our analysis of quality improvement, the profit margin falls immediately after an enterprise improves its product quality due to increased costs without increased sales revenue initially. Indeed, these enterprises may cut prices to attempt to increase market share and gain a reputation for product quality. Over time, the gap between the perceived quality and the actual quality narrows as the enterprise gains a reputation for high quality products and sales revenues increases. We measure performance as value added with subsidiaries included in an enterprise group. We also consider the causes and effects of an increase in the share of the new marketing channels. Although this variable reflects an enterprise's efforts to expand its marketing network, it may also be related to its performance in that potential sales agencies choose suppliers based on their reputations.

We specify the following reduced-form regressions.

$$
\begin{aligned}
& V_{i}=\alpha_{0}+\alpha_{V} V_{i}^{\prime}+\alpha_{C} C_{i}^{\prime}+\alpha_{M} M_{i}^{\prime}+\alpha_{E} E_{i}^{\prime}+X_{i} \alpha_{X}+u_{i}, \\
& C_{i}=\beta_{0}+\beta_{V} V_{i}^{\prime}+\beta_{C} C_{i}^{\prime}+\beta_{M} M_{i}^{\prime}+\beta_{E} E_{i}^{\prime}+X_{i} \beta_{X}+v_{i}, \\
& M_{i}=\gamma_{0}+\gamma_{V} V_{i}^{\prime}+\gamma_{C} C_{i}^{\prime}+\gamma_{M} M_{i}^{\prime}+\gamma_{E} E_{i}^{\prime}+X_{i} \gamma X+w_{i},
\end{aligned}
$$

where $V$ is the logarithm of value added, $C$ is the percentage share of the new marketing channels, and $M$ is the profit margin. The variables with primes on the right-hand side of the equations are lagged by five years. In addition, $E$ is the proportion of workers who 
were engineers, $X$ is a vector of characteristics of the manager, e.g., occupational background and schooling years, and $u, v$, and $w$ are disturbance terms. These equations are estimated for two periods separately because the coefficients are expected to change over time. In the Appendix, we report the results of regressions in which we pool the two periods and control for unobserved heterogeneity among enterprises.

Table 7 displays the expected effects of the lagged dependent variables and the employment of engineers separately for the leaders and other enterprise types and for the two periods. The leaders had hired more engineers to improve the quality of products and production processes by 1990 , which should promote sales and contribute to high profits in the first period. Hence, $\alpha_{E}, \beta_{E}$, and $\gamma_{E}$ are expected to be positive. An initially thin profit margin should contribute to increases in value added, the share of new marketing channels, and profit margin so that $\alpha_{M}, \beta_{M}$, and $\gamma_{M}$ should be negative. An increase in the share of the new marketing channels should increase value added, as the positive sign of $\alpha_{C}$ indicates. Since the relative sizes of the leaders and their marketing channels do not change much from 1990 to $1995, \alpha_{V}$ and $\beta_{C}$ should be positive. Unlike the leaders, other enterprises did not act to improve product quality in the first period. Their relative sizes were unchanged, new marketing channels were not explored, and profit margins remain as before. Hence, the expected signs of $\alpha_{V}, \beta_{C}$, and $\gamma_{M}$ are all positive but no other 
coefficients should be significant for the non-leaders.

By 1995, the gap between the perceived quality and the actual quality had narrowed for the leaders. In the second period, leaders are able to reap the benefits of their quality reputation. Hence, the lagged effects of value-added and increased share of new marketing channels should have positive effects on all three dependent variables. However, the effects of the lagged profit margin and the share of engineers are ambiguous for the leaders because aggressively low pricing and the employment of engineers are no longer important strategies. The followers and some of the laggards imitated the leaders by improving product quality and upgrading both their production processes and their marketing strategies. Hence, the signs of the coefficients for the other enterprises in the second period should be the same as those for the leaders in the first period with an important exception. The other enterprises could improve product quality and upgrade production process through imitation without increasing $E$ as much as the leader had in the early 1990s. Hence, although positive, the significance of $\alpha_{E}, \beta_{E}$, and $\gamma_{E}$ are expected to be lower.

Although we cannot test these expected differences between leaders and non-leaders because we have only six leaders in our sample, we can compare combined effects between the two periods. Since the expected signs of $\gamma_{M}$ are opposite for leaders 
and non-leaders, we assume the profit margin effect to be ambiguous. For the other coefficients, the expected signs are clear from Table 7. To summarize, we have three testable hypotheses. First, value added and the share of new marketing channels increased with the initial employment of engineers in the early 1990s, but these effects became weaker in the late 1990 s because imitation reduced the importance of engineers in upgrading quality and improving production processes. Second, an initially thin profit margin contributed to growth in value added and increases in the share of new marketing channels in both periods, but its contribution to profit margin became stronger in the later period. Third, the positive effects of value added increase over time because of the reputation effect.

In the reduced-form equations, all explanatory variables are predetermined or exogenous so that endogeneity is not a concern. Although ordinary least squares (OLS) is appropriate for estimating equations (1) and (3), it is inappropriate for equation (2) because the dependent variable is censored. Hence, we use the one-limit tobit method for the first period and the two-limit tobit method for the second period. In the tobit estimation, we must consider possible biases due to heteroskedasticity. The variance of the disturbance term is likely to be greater for smaller enterprises, for which the dependent variable can be affected more easily by even a slight change in the number of sales agencies and own retail 
outlets. To cope with this problem, we adopt the multiplicative tobit method and assume that the variance takes the form denoted by $\sigma_{i}^{2}=\exp \left(\delta_{0}+\delta_{1} V_{i}^{\prime}\right)$, where the coefficient $\delta_{1}$ is expected to be negative. ${ }^{13}$

\section{Estimation Results}

Tables 8 and 9 present the estimated coefficients for each period separately. ${ }^{14}$ In the first period, the employment of engineers has a positive and highly significant effect in each equation as expected. However, profit margins do not have the expected negative effect either on value added or on the share of the new marketing channels if the employment of engineers is included in the regressions. However, without the engineer variable, profit margins have negative and significant effects, which may be attributable to correlation between these two variables. Perhaps low profit margins for the leaders are associated with the high employment of engineers in 1990.

The effect of lagged profit margin is positive and significant on the profit margin if the engineer variable is included but insignificant otherwise. The effect of profit margins is positive due to the behavior of non-leaders. As expected, the share of the new marketing channels has a positive and significant effect on value added. Most dummy variables representing the managers' former occupations are insignificant indicating that 
prior experience in commerce, which is the default category, was not particularly advantageous even though the majority of new entrants to the industry were former merchants in the early 1990s. The only meaningful exception is the positive effect of managerial experience in developing new marketing channels. Finally, the positive and significant effect of the years of schooling on value added indicates the importance of education in organizing production efficiently.

The effects of value added and the share of the new marketing channels in 1990 on the corresponding variables in 1995 are positive and significant as expected. If all the enterprises had grown at the same rate regardless of their initial sizes, these coefficients would have been unity. Since they are significantly smaller than unity, smaller enterprises grew faster than larger ones. From Figure 2, the innovator was by far the largest enterprise in 1990 but the other leaders became larger and the followers began to catch up by 1995 . Table 8 provides three reasons for the leaders' high growth during this period, namely, large employment of engineers relative to enterprise size, a low-price policy, and their managers' relatively high education.

For the regressions in columns (i), (iii), and (v) of Table 9, the full sample of enterprises is used. However, the converts are not equivalent to other enterprises with respect to selling products through the distribution channels of their principal enterprises. 
Hence, this table also reports regressions in which the converts are excluded in columns (ii), (iv), and (vi). Without the converts, the $t$-statistics are generally smaller due to the reduction in the sample size but the qualitative results are similar. The coefficients in Table 9 are considerably different from those in Table 8 . The coefficient for value added in the value added equation is equal to unity. The effects of initial value added on both the share of the new market channels and profit margins are now positive and significant, while the effect of new marketing channels on value added is also positive and significant. These results support our third hypothesis that the positive effects of value added increase due to reputation effects in the later period. The negative and significant effects of initial profit margins on the three dependent variables are consistent with our second hypothesis that predicts a stronger effect of lower profit margin in the later period. The effects of the employment of engineers are no longer significant, as the first hypothesis asserts. Although the employment of engineers contributes to the improvement of product quality in the long run, this contribution decreases over time as the imitation of high-quality products becomes easier. The other differences between periods are the positive effect of the engineer dummy and the negative and significant effect of the years of top management on value added in the later period suggesting that engineering expertise and new management leadership became more important as the industry developed. 
To summarize our empirical results, the employment of engineers lost its importance and the contribution of initially thin profit margins to growth performance became stronger over time. Hence, the imitation of product quality and of better production processes is evident as is strategic pricing. Moreover, as the leaders' reputations became established, the reputation effect strengthened. Enterprises that failed to imitate high quality products or marketing strategies were forced to abandon their own brand names and to become subsidiaries of large enterprises. As a result, enterprise groups grew rapidly and reaped the returns on their past investment in reputation. Our empirical results support this explanation of the explosive expansion of industry in the late 1990s in Wenzhou.

\section{Conclusions}

Wenzhou had a unique set of initial conditions; hence, the replicability of Wenzhou's rapid industrial development in other poor rural areas is an important issue. To assess this possibility, we investigate the basics characteristics of the Wenzhou model by focusing on the evolutionary development of the low-voltage electric appliance industry. In developing countries, the evolutionary process of industrial development begins with the imitation of easy-to-produce items rather than with product innovation, once a market has been identified. Similarly, the entry of many small enterprises occurred after the 
construction of a local marketplace in Wenzhou. However, as these enterprises expanded beyond the local marketplace, marketing expertise became important because of the high transaction costs associated with these activities in all of the less-developed and transition economies. We find that the ratio of former merchants among new entrants increased in Wenzhou. Therefore, the Wenzhou experience confirms the critical roles of marketplaces and merchants in the early stage of industrial development.

As the number of enterprises producing poor-quality products increases, their market becomes saturated so that improved product quality is profitable and inevitable. Whether the major innovation requires engineering knowledge or marketing expertise hinges on the nature of the product of the industry. In technologically simple industries in remote areas, such as in Wenzhou, marketing expertise is particularly important because improving product quality is easier than marketing the improved product. Moreover, in less developed areas, poor-quality products prevail so that asymmetric information will be a serious problem. Hence, investment in reputation and other marketing strategies will be indispensable. Our paper demonstrates that the introduction of new marketing strategies, such as the use of brand names and exclusive sales agencies by a former merchant and their imitation by a number of followers were crucial to the growth of the industry. Therefore, merchant-led industrial development characterizes the Wenzhou model, and can be 
replicated in other parts of the developing world that have a tradition of commerce.

\section{Appendix: Panel Regressions}

To check the robustness of the estimation results reported in Tables 8 and 9, we use panel data to estimate regressions in which we control for unobserved heterogeneity among enterprises. We modify equations (1) through (3) in the following manner:

$$
Y_{i t}=\rho_{0}+\rho_{1} V_{i t}^{\prime}+\rho_{2} S_{t} V_{i t}^{\prime}+\rho_{3} C_{t}^{\prime}+\rho_{4} M_{i t}^{\prime}+\rho_{5} S_{t} M_{i t}^{\prime}+\rho_{6} E_{i t}^{\prime}+\rho_{7} S_{t} E_{i t}^{\prime}+\lambda_{i}+\rho_{8} S_{t}+\varepsilon_{i t},
$$

where $Y_{i t}$ is the dependent variable, i.e., $V_{i t}, C_{i t}$, or $M_{i t}$, the subscript $t$ indicates year 1995 or 2000, $S_{t}$ is a second-period dummy which is zero for 1995 and one for $2000, \lambda_{i}$ is the enterprise effect capturing both observed and unobserved characteristics of enterprises, and $\mathcal{E}_{i t}$ is an error term. Interaction terms, i.e., $S V^{\prime}, S M^{\prime}$, and $S E^{\prime}$, are included to capture the changes in the effects of value added, profit margin, and engineer employment, which were predicted by the hypotheses and confirmed in Tables 8 and 9 . We use both a fixed-effects estimator and a random-effects GLS estimator. Although consistent estimators for dynamic panel data are found in the literature, e.g., Baltagi (1995), these techniques are not applicable to our data because the number of time-series observations is too small. Furthermore, the limited nature of the dependent variable in the new marketing channel equation must be ignored due to the small sample size. 
The estimated coefficients are reported in Table A1. The full sample is used in the first two columns for each dependent variable, but the sub-sample that excludes converts is used in the third column. The effects of lagged value added on the three dependent variables are positive and generally significant; the interaction term between value added and the second-period dummy is positive with one exception. Hence, support for the third hypothesis is confirmed. Consistent with the second hypothesis, the profit margin has negative effects on value added and the new marketing channel share. Moreover, the coefficient for the interaction term of the profit margin and the second-period dummy is negative and highly significant, which supports the assertion that the effect of low profit margin is stronger in the later period. According to the first hypothesis, the employment of engineers should have positive effects on value added and the new marketing channel share, but the interaction term should be negative. Although the fixed-effects estimates of these effects are not statistically significant, the random-effect estimates in columns 1 and 4 do support this hypothesis. 


\section{Notes}

1. We thank Yujiro Hayami, Michiki Kikuchi, Justin Y. Lin, Scott Rozelle, Deqiang Liu, Michael Kevane, John Bonin and four anonymous referees for very helpful comments. We also thank Paul Kandasamy and Mayuko Tanaka for their editorial advice and assistance.

2. According to Li (1997), Wenzhou had as many as 528 specialized markets, of which 114 markets specialized in different parts, materials, and machines for industrial production and construction and the rest dealt in consumption goods.

3. The qualitative pattern of development in the garment and footwear industries did not differ substantially from that in the low-voltage electric appliance industry.

4. Thus, this paper neglects the inter-enterprise division of labor even though we think that it plays an important role in the development of the industry.

5 Sonobe, Hu, and Otsuka (2002) find a similar tendency in a cluster of garment enterprises in the northern part of Zhejiang Province.

6. Describing twelve successful entrepreneurs in Wenzhou in the 1980s, Zhang (1989) points out that many had worked for other factories in the past.

7. Smyth and $\mathrm{Lu}$ (2000) discuss the formulation of large enterprise groups in the late 1990s. 
8. No enterprise in the sample originated as a subsidiary.

9. In most cases, the year of group formation is earlier than the year in which the enterprise was registered officially as a group.

10. The use of migrant merchants as sales agencies is common in garment, footwear, and many other industries in Wenzhou (Wang, 1996). However, this arrangement is not practiced by garment enterprises in some other areas according to our interview with the sales manager of a garment enterprise in Wuhan in Hubei Province.

11. By 1990, the enterprise that first introduced quality inspection was separated into two enterprises so that we classify both of these as leaders.

12. Since some subsidiaries supplied parts to their parent enterprises, total sales revenue is an inappropriate measure of size.

13. Greene (2000) provides details of this method.

14. The condition number of the moments matrix $\boldsymbol{X}^{\boldsymbol{X}} \boldsymbol{X}$, where $\boldsymbol{X}$ is the matrix of the explanatory variables, is much less than 20 for each period and for each set of explanatory variables used in the regressions. Hence, no serious multicollinearity exists in the data. 


\section{References}

Akerlof, George A., 1970. The Market for 'Lemons': Quality Uncertainty and the Market Mechanism. Quarterly Journal of Economics 84 (3), 488-500.

Baltagi, Badi H., 1995. Econometric Analysis of Panel Data. Wiley, Chichester, UK.

Chen, Kang, Jefferson, Gary H., and Singh, Inderjit, 1992. Lessons from China's Economic Reform. Journal of Comparative Economics 16, 201-25.

Dong, Fureng, 1990. The Wenzhou Model for Developing the Rural Commodity Economy. In: Nolan, Peter, Fureng, Dong (Eds.), Market Forces in China: Competition and Small Business - The Wenzhou Debate. Zed Books, London, pp. 77 - 96.

Filson, Darren, 2002. Product and Process Innovations in the Life of an Industry. Journal of Economic Behavior and Organization 49 (1), 97-112.

Friedmann, John, 2003. China's Urbanization. International Journal of Urban and Regional Research 27 (3), 745-58.

Gort, Michael, and Klepper, Steven, 1982. Time Paths in the Diffusion of Product Innovations. Economic Journal 92 (367), 630-653.

Greene, William H., 2000. Econometric Analysis, 4th Edition. Prentice-Hall, New Jersey.

Jefferson, Gary. H., Rawski, Thomas. G., and Zheng, Yuxin, 1996. Chinese Industrial Productivity: Trends, Measurement, and Recent Developments. Journal of 
Comparative Economics 23 (2), 146-180.

Jovanovic, Boyan, and MacDonald, Glenn, 1994a. Competitive Diffusion. Journal of Political Economy 102 (1), 24-52.

Jovanovic, Boyan, and MacDonald, Glenn, 1994b. The Life Cycle of a Competitive Industry. Journal of Political Economy 102 (2), 322-347.

Klein, Benjamin, and Leffler, Keith B., 1981. The Role of Market Force in Assuring Contractual Performance. Journal of Political Economy 89 (4), 615-641.

Klepper, Steven, 1996. Entry, Exit, Growth, and Innovation over the Product Life Cycle. American Economic Review 86 (3), 562-583.

Klepper, Steven, 2002. Firm Survival and the Evolution of Oligopoly. RAND Journal of Economics 33, 37-61.

Klepper, Steven, and Simons, Kenneth. L., 2000. The Making of Oligopoly: Firm Survival and Technological Change in the Evolution of the U.S. Tire Industry. Journal of Political Economy 108 (4), 728-760.

Landes, David S., 1969. The Unbound Prometheus. Cambridge University Press, Cambridge, UK.

Li, Dingfu, 1997. Wenzhou zhi Mi: Zhongguo Tuopinzhifu de Chenggong Moshi (The Enigma of Wenzhou: The Successful Model of the Transition from Poverty to 
Affluence in China). Gaige Chubanshe, Beijing.

Murphy, Rachel, 2002. Return Migration, Entrepreneurship, and State-Sponsored Urbanization in the Jiangxi Countryside. In: Logan, John R. (Ed.), The New Chinese City: Globalization and Market Reform. Blackwell, Oxford, UK.

Nolan, Peter, 1990. Petty Commodity Production in a Socialist Economy: Chinese Rural Development post-Mao. In: Nolan, Peter and Dong, Fureng (Eds.), Market Forces in China: Competition and Small Business-The Wenzhou Debate. Zed Books, London.

Otsuka, Keijiro, 1998. Rural Industrialization in East Asia. In: Hayami, Yujiro, Aoki, Masahiko (Eds.), The Institutional Foundations of East Asian Economic Development. Palgrave Macmillan, Basingstoke/London, pp. 447-475.

Otsuka, Keijiro, Liu, Deqiang, and Murakami, Naoki, 1998. Industrial Reform in China: Past Performance and Future Prospects. Clarendon Press, Oxford.

Schumpeter, Joseph A., 1912. The Theory of Economic Development. Oxford University Press, New York.

Shapiro, Carl, 1983. Premiums for High Quality Products as Returns to Reputations. Quarterly Journal of Economics 98 (4), 659-679.

Shiba, Yoshinobu, 1968. So-dai Shogyo-shi Kenkyu (Commercial Activities during the 
Sung Dynasty). Kazama Shobo, Tokyo.

Shiba, Yoshinobu, 1977. Ningpo and its Hinterland. In: Skinner, G. William (Ed.), The City in Late Imperial China. Stanford University Press, Stanford, CA.

Skinner, G. William, 1977. Introduction: Urban Social Structure in Ch'ing China. In: Skinner, G. William (Ed.), The City in Late Imperial China. Stanford University Press, Stanford, CA.

Smyth, Russell, and Lu, Zeng-Hua, 2000. A Model Formalising the Trade-Offs between Collective Learning and Specialisation in the Collective Township and Village Enterprises Sector in China. Asian Economic Review 42 (2), 263-278

Sonobe, Tetsushi, Hu, Dinghuan, and Otsuka, Keijiro, 2002. Dynamic Process of Cluster Formation and the Role of Traders: A Case Study of a Garment Town in China. Journal of Development Studies 39(1), 118-139

Sonobe, Tetsushi, Kawakami, Momoko, and Otsuka, Keijiro, 2003. Changing Role of Innovation and Imitation in Development: The Case of the Machine Tool Industry in Taiwan. Economic Development and Cultural Change 52(1), 103-128

State Statistical Bureau, 2002. China Statistical Yearbook. China Statistics Press, Beijing. Statistical Bureau of Zhejiang Province, 2000. Comprehensive Statistical Data and Materials on 50 years of New Zhejiang. China Statistics Press, Beijing. 
Statistical Bureau of Zhejiang Province, 2000, 2001, and 2002. Zhejiang Statistical Yearbook. China Statistics Press, Beijing.

Wang, Ruliang, 1996. Wenzhou Cangnan Gaige Kaifang Jishi (The Chronicle of the Reform in Cangnan, Wenzhou). Xinhua Chubanshe, Beijing.

Yamamura, Eiji, Sonobe, Tetsushi, and Otsuka, Keijiro, 2003. Human Capital, Cluster Formation, and International Relocation: The Case Study of the Garment Industry in Japan, 1968-98. Journal of Economic Geography 3 (1), 37-56.

Zhang, Liz, 2001. Strangers in the City: Reconfigurations of Space, Power, and Social Networks within China's Floating Population. Stanford University Press, Stanford, CA.

Zhang, Renshou, 1999. Zhejiang Nongcun Jingji Gaige Tixi Yanjiu (The Systematic Review of Economic Transition in Zhejiang Rural Area). Zhejiang Renming Chubanshe, Hangzhou.

Zhang, Zhiren, 1989. Wenzhou Chao (Wenzhou Tide). Wenhua Yishu Chubanshe, Beijing. 
TABLE 1

Characteristics of Enterprise Founders

\begin{tabular}{lccccc}
\hline & $\begin{array}{c}\text { Before } \\
1980\end{array}$ & $1981-85$ & $1986-90$ & $1991-95$ & $1995-2000$ \\
\hline No. of enterprises & 4 & 32 & 30 & 36 & 10 \\
\hline Years of schooling & 8.0 & 9.8 & 10.0 & 10.5 & 10.9 \\
\hline Occupation (\%) & 50 & 12.5 & 6.7 & 2.8 & 0 \\
$\begin{array}{l}\text { Farmers } \\
\text { Factory workers }\end{array}$ & 0 & 25 & 16.7 & 16.7 & 10 \\
Salesmen or & 25 & 25 & 43.3 & 63.9 & 50 \\
traders & 0 & 3.1 & 13.3 & 5.6 & 0 \\
Engineers & 0 & 9.4 & 10 & 5.6 & 10 \\
Managers & 25 & 25 & 10 & 5.6 & 30 \\
Others & & & & & \\
\hline
\end{tabular}


TABLE 2

Descriptive Statistics

\begin{tabular}{lccc}
\hline & 1990 & 1995 & 2000 \\
\hline $\begin{array}{l}\text { Number of enterprises } \\
\text { Number of independent } \\
\text { Enterprises }\end{array}$ & 66 & 102 & 112 \\
Sales revenue & 66 & 96 & 73 \\
Value added & 320.4 & 964.1 & 9525.7 \\
Number of employees & 123.7 & 375.8 & 3671.4 \\
Capital stock & 46.7 & 104.1 & 338.3 \\
\hline Notes: & 372.0 & 983.9 & 7922.1 \\
\hline
\end{tabular}

Notes:

(i) Production and employment sizes reported are averages of the existing sample enterprises in each year. Although some of the sample enterprises had subsidiaries, the numbers shown here do not include subsidiaries.

(ii) The data on enterprise sizes refer only to the independent enterprises.

(iii) Values are in real terms using 2000 prices as a base and measured in 10,000 yuan. The deflator is the ex-factory price index for the electric machinery and equipment industry compiled by the Statistical Bureau of Zhejiang Province (Zhejiang Statisitical Yearbook, various years). 
TABLE 3

Enterprises Group Formation

\begin{tabular}{lccccc}
\hline & $\begin{array}{c}\text { Before } \\
1990\end{array}$ & $\begin{array}{c}\text { Early } \\
1990 \mathrm{~s}\end{array}$ & $\begin{array}{c}\text { Late } \\
1990 \mathrm{~s}\end{array}$ & $\begin{array}{c}\text { Not until } \\
2000\end{array}$ & $\begin{array}{c}\text { Merged } \\
\text { by 2000 }\end{array}$ \\
\hline No. of enterprises & 1 & 5 & 20 & 47 & 39 \\
\hline $\begin{array}{l}\text { Established year } \\
\begin{array}{l}\text { Years of schooling of } \\
\text { managers }\end{array}\end{array}$ & 1986 & 1982 & 1987 & 1990 & 1990 \\
\hline Notes: & 13 & 13.0 & 10.9 & 10.4 & 10.4 \\
\hline
\end{tabular}

(i) Enterprises in the second-to-last columns were independent at least until 2000 and had not formed enterprise groups. 
TABLE 4

Characteristics of Enterprises

\begin{tabular}{lccc}
\hline & 1990 & 1995 & 2000 \\
\hline $\begin{array}{l}\text { Proportion of workers that } \\
\text { are engineers (\%) }\end{array}$ & 1.5 & 2.7 & 4.2 \\
\hline $\begin{array}{l}\text { Number of parts supplying } \\
\text { subcontractors }\end{array}$ & 0 & 2.8 & 34.8 \\
\hline $\begin{array}{l}\text { Composition of marketing channels (\%) } \\
\text { Local wholesale market }\end{array}$ & 23.5 & 20.4 & 3.6 \\
Wenzhou traders & 26.5 & 23.8 & 5.7 \\
Sales agencies & 22.0 & 30.7 & 50.6 \\
Own retail outlets & 9.5 & 12.6 & 27.1 \\
& 18.5 & 12.5 & 13.0 \\
\hline
\end{tabular}

Notes:

(i) The proportion of workers that are engineers is a weighted average with the share of each enterprise's employment in the total employment of the independent enterprises as weights.

(ii) The composition of marketing channels is a weighted average with the ratios of each enterprise's sale to the total sales of the independent enterprises as weights. 
TABLE 5

New Marketing Strategies

\begin{tabular}{|c|c|c|c|}
\hline & 1990 & 1995 & 2000 \\
\hline $\begin{array}{l}\text { Full-scale use of sales } \\
\text { agencies }\end{array}$ & 12.9 & 42.7 & 56.0 \\
\hline Use of brand name & 50.0 & 72.9 & 98.6 \\
\hline $\begin{array}{l}\text { Certification of national } \\
\text { standard }\end{array}$ & 43.5 & 72.9 & 91.8 \\
\hline $\begin{array}{l}\text { Certification of } \\
\text { international standard }\end{array}$ & 4.8 & 15.6 & 54.8 \\
\hline $\begin{array}{ll}\text { Notes: } & \\
\text { (i) } & \text { The table reports t } \\
\text { (ii) } & \text { This sample does } \mathrm{r}\end{array}$ & $\begin{array}{l}\text { of sa } \\
\text { ibsidi }\end{array}$ & $\mathrm{s}$ adop & \\
\hline
\end{tabular}


TABLE 6

Classification of Enterprises

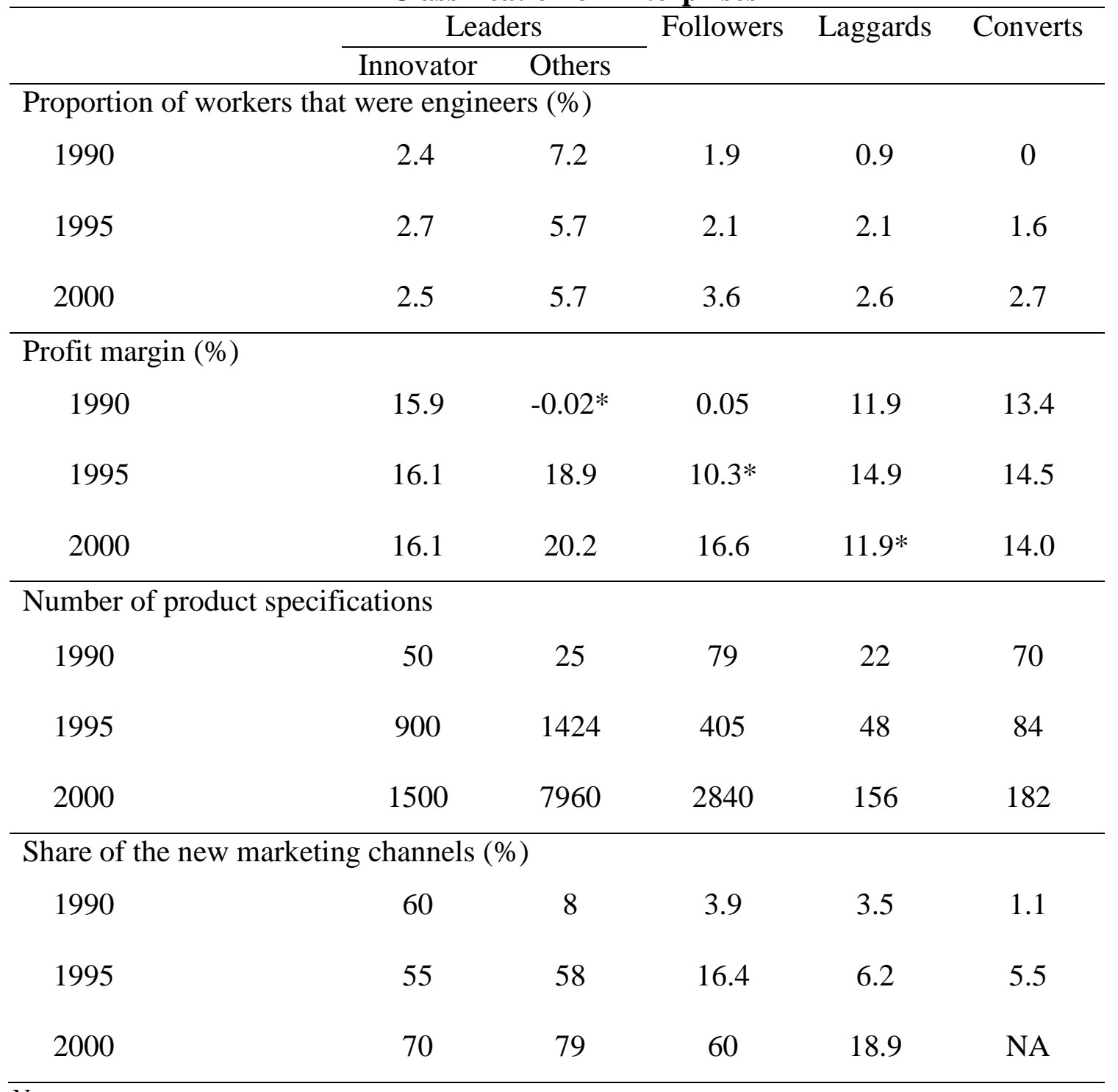

\section{Notes:}

(i) Enterprises are classified according to the timing of the formation of an enterprise group.

(ii) The symbol $*$ indicates that the enterprise type had the lowest average in that particular year.

(iii) The average in the last column is taken over the converts that were independent in the particular year. By definition the converts did not have sales networks because they were subsidiaries in 2000. 
TABLE 7

Expected Signs of Coefficients

\begin{tabular}{|c|c|c|c|c|c|c|}
\hline \multirow[b]{2}{*}{ Eq. } & \multirow[b]{2}{*}{$\begin{array}{c}\text { Dependent } \\
\text { Variable }\end{array}$} & \multirow[b]{2}{*}{ Coefficient } & \multicolumn{2}{|c|}{$1990-1995$} & \multicolumn{2}{|c|}{$1995-2000$} \\
\hline & & & $\begin{array}{c}\text { Leaders } \\
\text { (i) }\end{array}$ & $\begin{array}{l}\text { Others } \\
\text { (ii) }\end{array}$ & $\begin{array}{c}\text { Leaders } \\
\text { (iii) }\end{array}$ & $\begin{array}{l}\text { Others } \\
\text { (iv) }\end{array}$ \\
\hline \multirow{4}{*}{ (1) } & \multirow{4}{*}{$\begin{array}{l}\text { Value } \\
\text { added }\end{array}$} & $\alpha_{V}$ & + & + & + & + \\
\hline & & $\alpha_{C}$ & + & & + & + \\
\hline & & $\alpha_{M}$ & - & & & - \\
\hline & & $\alpha_{E}$ & + & & & $(+)$ \\
\hline \multirow{4}{*}{ (2) } & \multirow{4}{*}{$\begin{array}{c}\text { Share of } \\
\text { new } \\
\text { marketing }\end{array}$} & $\beta_{V}$ & & & + & \\
\hline & & $\beta_{C}$ & + & + & + & + \\
\hline & & $\beta_{M}$ & - & & & - \\
\hline & & $\beta_{E}$ & + & & & $(+)$ \\
\hline \multirow{4}{*}{ (3) } & \multirow{4}{*}{$\begin{array}{l}\text { Profit } \\
\text { margin }\end{array}$} & $\gamma_{V}$ & & & + & \\
\hline & & $\gamma_{C}$ & & & + & \\
\hline & & $\gamma_{M}$ & - & + & & - \\
\hline & & $\gamma_{E}$ & + & & & $(+)$ \\
\hline
\end{tabular}

Notes:

(i) A positive (negative) sign indicates that the effect is expected to be positive (negative) and statistically significant.

(ii) The symbol (+) indicates that the effect is expected to be positive but only weakly significant at best. 
TABLE 8

First-Period Regression Analysis

\begin{tabular}{|c|c|c|c|c|c|c|}
\hline \multirow[t]{3}{*}{ Dependent Variable } & \multicolumn{2}{|c|}{$\ln$ (value added) 1995} & \multicolumn{2}{|c|}{$\begin{array}{c}\text { New marketing } \\
\text { channel share } 1995(\%)\end{array}$} & \multicolumn{2}{|c|}{ Profit margin 1995 (\%) } \\
\hline & \multicolumn{2}{|c|}{ OLS } & \multicolumn{2}{|c|}{ Multiplicative tobit } & \multicolumn{2}{|c|}{ OLS } \\
\hline & (i) & (ii) & (iii) & (iv) & (v) & (vi) \\
\hline $\ln$ (value added) 1990 & $\begin{array}{c}0.555^{* * *} \\
(3.98)\end{array}$ & $\begin{array}{c}0.639 * * \\
(4.52)\end{array}$ & $\begin{array}{l}-2.800 \\
(-0.64)\end{array}$ & $\begin{array}{l}0.033 \\
(0.00)\end{array}$ & $\begin{array}{l}-0.826 \\
(-1.16)\end{array}$ & $\begin{array}{l}-0.469 \\
(-0.66)\end{array}$ \\
\hline $\begin{array}{l}\text { New marketing } \\
\text { channel share }{ }_{1990}(\%)\end{array}$ & $\begin{array}{l}0.019 \\
(1.46)\end{array}$ & $\begin{array}{c}0.027 * \\
(1.95)\end{array}$ & $\begin{array}{l}1.103 * * \\
(4.55)\end{array}$ & $\begin{array}{l}1.172 * * \\
(3.14)\end{array}$ & $\begin{array}{c}0.053 \\
(1.11)\end{array}$ & $\begin{array}{l}0.091 \\
(1.47)\end{array}$ \\
\hline Profit margin ${ }_{1990}(\%)$ & $\begin{array}{l}-0.013 \\
(-1.02)\end{array}$ & $\begin{array}{c}-0.036^{* *} \\
(-3.18)\end{array}$ & $\begin{array}{l}-0.130 \\
(-0.54)\end{array}$ & $\begin{array}{c}-0.627 * \\
(-1.74)\end{array}$ & $\begin{array}{c}0.149^{*} \\
(1.76)\end{array}$ & $\begin{array}{l}0.031 \\
(0.32)\end{array}$ \\
\hline $\begin{array}{l}\text { Employment of } \\
\text { engineers } 1990(\%)\end{array}$ & $\begin{array}{c}0.183 * * \\
(3.30)\end{array}$ & & $\begin{array}{c}3.797 * * \\
(4.01)\end{array}$ & & $\begin{array}{c}0.935 * * \\
(3.01)\end{array}$ & \\
\hline Farmer dummy & $\begin{array}{l}0.359 \\
(0.76)\end{array}$ & $\begin{array}{l}0.624 \\
(1.22)\end{array}$ & $\begin{array}{l}6.414 \\
(0.57)\end{array}$ & $\begin{array}{l}18.05 \\
(1.11)\end{array}$ & $\begin{array}{l}-2.227 \\
(-0.59)\end{array}$ & $\begin{array}{l}-0.889 \\
(-0.25)\end{array}$ \\
\hline Factory worker dummy & $\begin{array}{l}-0.112 \\
(-0.26)\end{array}$ & $\begin{array}{l}-0.259 \\
(-0.58)\end{array}$ & $\begin{array}{l}6.391 \\
(0.59)\end{array}$ & $\begin{array}{l}-6.916 \\
(-0.39)\end{array}$ & $\begin{array}{l}-2.656 \\
(-0.92)\end{array}$ & $\begin{array}{l}-3.349 \\
(-1.09)\end{array}$ \\
\hline Engineer dummy & $\begin{array}{l}-0.307 \\
(-0.52)\end{array}$ & $\begin{array}{l}0.044 \\
(0.07)\end{array}$ & $\begin{array}{l}-27.01 \\
(-0.71)\end{array}$ & $\begin{array}{l}13.81 \\
(0.35)\end{array}$ & $\begin{array}{l}-3.526 \\
(-1.01)\end{array}$ & $\begin{array}{l}-1.821 \\
(-0.51)\end{array}$ \\
\hline Manager dummy & $\begin{array}{l}-0.034 \\
(-0.06)\end{array}$ & $\begin{array}{l}0.123 \\
(0.21)\end{array}$ & $\begin{array}{l}31.60 * * \\
(2.85)\end{array}$ & $\begin{array}{l}36.17 * \\
(2.09)\end{array}$ & $\begin{array}{l}-5.455 \\
(-1.12)\end{array}$ & $\begin{array}{l}-4.702 \\
(-1.12)\end{array}$ \\
\hline $\begin{array}{l}\text { Other occupations } \\
\text { Dummy }\end{array}$ & $\begin{array}{l}0.036 \\
(0.09)\end{array}$ & $\begin{array}{l}0.147 \\
(0.34)\end{array}$ & $\begin{array}{l}11.04 \\
(1.39)\end{array}$ & $\begin{array}{l}30.97 * \\
(2.11)\end{array}$ & $\begin{array}{l}-1.790 \\
(-0.68)\end{array}$ & $\begin{array}{l}-0.709 \\
(-0.29)\end{array}$ \\
\hline Years of schooling & $\begin{array}{c}0.153 * * \\
(3.09)\end{array}$ & $\begin{array}{l}0.120^{*} \\
(2.24)\end{array}$ & $\begin{array}{l}1.820 \\
(1.63)\end{array}$ & $\begin{array}{l}1.826 \\
(1.06)\end{array}$ & $\begin{array}{l}0.272 \\
(0.71)\end{array}$ & $\begin{array}{l}0.125 \\
(0.30)\end{array}$ \\
\hline $\begin{array}{l}\text { Years of top } \\
\text { Management }\end{array}$ & $\begin{array}{l}-0.048 \\
(-1.20)\end{array}$ & $\begin{array}{l}0.016 \\
(0.40)\end{array}$ & $\begin{array}{l}-0.382 \\
(-0.44)\end{array}$ & $\begin{array}{l}1.193 \\
(0.86)\end{array}$ & $\begin{array}{l}-0.331 \\
(-0.94)\end{array}$ & $\begin{array}{l}-0.005 \\
(-0.02)\end{array}$ \\
\hline Constant & $\begin{array}{c}1.777 * \\
(2.11)\end{array}$ & $\begin{array}{l}1.532^{*} \\
(1.68)\end{array}$ & $\begin{array}{l}-11.22 \\
(-0.40)\end{array}$ & $\begin{array}{l}-36.63 \\
(-0.83)\end{array}$ & $\begin{array}{c}16.18 * * \\
(2.66)\end{array}$ & $\begin{array}{c}15.04 * * \\
(2.43)\end{array}$ \\
\hline \multicolumn{7}{|c|}{ Correction for heteroskedasticity } \\
\hline $\ln$ (value added) in 1990 & NA & NA & $\begin{array}{c}-1.044 * * \\
(-3.32) \\
\end{array}$ & $\begin{array}{l}-0.381 \\
(-0.88) \\
\end{array}$ & NA & NA \\
\hline R-squared & 0.66 & 0.57 & NA & NA & 0.20 & 0.11 \\
\hline
\end{tabular}

Notes:

(i) The sample size is 55 .

(ii) In the tobit regressions, 27 observations are left-censored at zero for the share of new marketing channels in 1995.

(iii) The numbers in parentheses are $t$-statistics.

(iv) The symbols $*$ and $* *$ indicate statistical significance at the $5 \%$ and $1 \%$ levels, respectively, for a one-sided test. 
TABLE 9

Second-Period Regression Analysis

\begin{tabular}{|c|c|c|c|c|c|c|}
\hline \multirow[t]{3}{*}{ Dependent Variable } & \multicolumn{2}{|c|}{$\ln$ (value added) 2000} & \multicolumn{2}{|c|}{$\begin{array}{c}\text { New marketing } \\
\text { channel share } 2000(\%)\end{array}$} & \multicolumn{2}{|c|}{ Profit margin $2000(\%)$} \\
\hline & \multicolumn{2}{|c|}{ OLS } & \multicolumn{2}{|c|}{ Multiplicative tobit } & \multicolumn{2}{|c|}{ OLS } \\
\hline & (i) & (ii) & (iii) & (iv) & $(\mathrm{v})$ & (vi) \\
\hline $\ln ($ value added) 1995 & $\begin{array}{l}1.062 * * \\
(13.38)\end{array}$ & $\begin{array}{c}1.105^{* *} \\
(8.82)\end{array}$ & $\begin{array}{l}21.73 * * \\
(3.86)\end{array}$ & $\begin{array}{l}10.49 * \\
(1.96)\end{array}$ & $\begin{array}{c}1.079 * * \\
(3.37)\end{array}$ & $\begin{array}{c}1.362 * * \\
(3.10)\end{array}$ \\
\hline $\begin{array}{l}\text { New marketing } \\
\quad \text { channel share }{ }_{1995}(\%)\end{array}$ & $\begin{array}{c}0.014 * * \\
(2.38)\end{array}$ & $\begin{array}{c}0.014^{*} \\
(1.73)\end{array}$ & $\begin{array}{c}0.665^{*} \\
(1.91)\end{array}$ & $\begin{array}{l}0.725^{* *} \\
(2.40)\end{array}$ & $\begin{array}{l}0.009 \\
(0.37)\end{array}$ & $\begin{array}{l}0.006 \\
(0.21)\end{array}$ \\
\hline Profit margin ${ }_{1995}(\%)$ & $\begin{array}{c}-0.059 * * \\
(-4.11)\end{array}$ & $\begin{array}{c}-0.059 * * \\
(-3.00)\end{array}$ & $\begin{array}{l}-2.062 * * \\
(-2.41)\end{array}$ & $\begin{array}{l}-1.520 * \\
(-2.00)\end{array}$ & $\begin{array}{l}-0.066 \\
(-1.13)\end{array}$ & $\begin{array}{c}-0.118^{*} \\
(-1.69)\end{array}$ \\
\hline $\begin{array}{l}\text { Employment of } \\
\text { engineers } 1995(\%)\end{array}$ & $\begin{array}{l}0.019 \\
(0.77)\end{array}$ & $\begin{array}{l}0.016 \\
(0.45)\end{array}$ & $\begin{array}{c}-0.120 \\
(0.08)\end{array}$ & $\begin{array}{l}-0.269 \\
(-0.18)\end{array}$ & $\begin{array}{l}0.036 \\
(0.37)\end{array}$ & $\begin{array}{l}0.081 \\
(0.66)\end{array}$ \\
\hline Farmer dummy & $\begin{array}{l}0.364 \\
(1.08)\end{array}$ & $\begin{array}{l}0.563 \\
(1.27)\end{array}$ & $\begin{array}{l}10.97 \\
(0.61)\end{array}$ & $\begin{array}{l}5.200 \\
(0.35)\end{array}$ & $\begin{array}{l}0.553 \\
(0.41)\end{array}$ & $\begin{array}{l}1.374 \\
(0.88)\end{array}$ \\
\hline Factory worker dummy & $\begin{array}{l}-0.075 \\
(-0.29)\end{array}$ & $\begin{array}{l}-0.267 \\
(-0.74)\end{array}$ & $\begin{array}{l}-10.64 \\
(-0.73)\end{array}$ & $\begin{array}{l}-8.071 \\
(-0.65)\end{array}$ & $\begin{array}{l}0.122 \\
(0.12)\end{array}$ & $\begin{array}{l}-0.954 \\
(-0.75)\end{array}$ \\
\hline Engineer dummy & $\begin{array}{l}0.698^{*} \\
(1.76)\end{array}$ & $\begin{array}{l}0.951 \\
(1.51)\end{array}$ & $\begin{array}{l}9.636 \\
(0.39)\end{array}$ & $\begin{array}{l}20.47 \\
(0.89)\end{array}$ & $\begin{array}{l}2.631 \\
(1.65)\end{array}$ & $\begin{array}{l}1.278 \\
(0.58)\end{array}$ \\
\hline Manager dummy & $\begin{array}{l}0.352 \\
(0.97)\end{array}$ & $\begin{array}{l}0.616 \\
(1.29)\end{array}$ & $\begin{array}{l}24.32 \\
(1.44)\end{array}$ & $\begin{array}{r}13.33 \\
(0.98)\end{array}$ & $\begin{array}{l}-0.247 \\
(-0.17)\end{array}$ & $\begin{array}{l}0.996 \\
(0.59)\end{array}$ \\
\hline $\begin{array}{l}\text { Other occupations } \\
\text { Dummy }\end{array}$ & $\begin{array}{l}0.575^{*} \\
(1.91)\end{array}$ & $\begin{array}{l}0.757^{*} \\
(1.75)\end{array}$ & $\begin{array}{l}2.279 \\
(0.14)\end{array}$ & $\begin{array}{l}-2.823 \\
(-0.19)\end{array}$ & $\begin{array}{r}1.276 \\
(1.05)\end{array}$ & $\begin{array}{l}0.920 \\
(0.61)\end{array}$ \\
\hline Years of schooling & $\begin{array}{l}0.021 \\
(0.57)\end{array}$ & $\begin{array}{l}0.063 \\
(1.21)\end{array}$ & $\begin{array}{l}-1.844 \\
(-1.04)\end{array}$ & $\begin{array}{l}0.035 \\
(0.02)\end{array}$ & $\begin{array}{l}-0.069 \\
(-0.47)\end{array}$ & $\begin{array}{l}0.022 \\
(0.12)\end{array}$ \\
\hline $\begin{array}{l}\text { Years of top } \\
\text { Management }\end{array}$ & $\begin{array}{l}-0.043^{*} \\
(-2.01)\end{array}$ & $\begin{array}{l}-0.045 \\
(-1.51)\end{array}$ & $\begin{array}{l}-1.781 \\
(-1.50)\end{array}$ & $\begin{array}{l}-1.094 \\
(-1.07)\end{array}$ & $\begin{array}{l}0.016 \\
(0.18)\end{array}$ & $\begin{array}{l}-0.043 \\
(-0.41)\end{array}$ \\
\hline Constant & $\begin{array}{c}1.869 * * \\
(3.32)\end{array}$ & $\begin{array}{l}1.155 \\
(1.40) \\
\end{array}$ & $\begin{array}{c}-49.41 * \\
(-1.79) \\
\end{array}$ & $\begin{array}{r}-3.462 \\
(-0.14) \\
\end{array}$ & $\begin{array}{c}9.563 * * \\
(4.21) \\
\end{array}$ & $\begin{array}{c}8.200^{* *} \\
(2.82) \\
\end{array}$ \\
\hline \multicolumn{7}{|c|}{ Correction for heteroskedasticity } \\
\hline $\ln$ (value added) in 1995 & NA & NA & $\begin{array}{c}-0.252 * \\
(-1.73)\end{array}$ & $\begin{array}{c}-0.409 * \\
(-2.08)\end{array}$ & NA & NA \\
\hline R-squared & 0.82 & 0.81 & NA & NA & 0.24 & 0.35 \\
\hline Number of observations & 95 & 62 & 95 & 62 & 95 & 62 \\
\hline
\end{tabular}

\section{Notes:}

(i) The sample size is 95 .

(ii) For the regressions in columns (ii), (iv), and (vi), only the 62 observations that were independent enterprises in 2000 are used.

(iii) In the tobit regression in (iii), 51 observations are left-censored at zero for the share of new channels in 2000, and 5 observations are right-censored at $100 \%$.

(iv) In the tobit regression in (iv), 18 observations are left-censored and 5 observations are right-censored.

(v) The numbers in parentheses are $t$-statistics.

(vi) The symbols $*$ and $* *$ indicate statistical significance at the $5 \%$ and $1 \%$ levels, respectively, for a one-sided test. 
Table A1. Pooled Regression Analysis

\begin{tabular}{|c|c|c|c|c|c|c|c|c|c|}
\hline \multirow[t]{3}{*}{ Dependent Valiable } & \multicolumn{3}{|c|}{$\ln ($ value added $)$} & \multicolumn{3}{|c|}{ New marketing channel share $(\%)$} & \multicolumn{3}{|c|}{ Profit margin $(\%)$} \\
\hline & $\begin{array}{c}\text { Random } \\
\text { effect }\end{array}$ & $\begin{array}{l}\text { Fixed } \\
\text { effect }\end{array}$ & $\begin{array}{l}\text { Fixed } \\
\text { effect }\end{array}$ & $\begin{array}{l}\text { Random } \\
\text { effect }\end{array}$ & $\begin{array}{l}\text { Fixed } \\
\text { effect }\end{array}$ & $\begin{array}{l}\text { Fixed } \\
\text { effect }\end{array}$ & $\begin{array}{l}\text { Random } \\
\text { effect }\end{array}$ & $\begin{array}{l}\text { Fixed } \\
\text { effect }\end{array}$ & $\begin{array}{l}\text { Fixed } \\
\text { effect }\end{array}$ \\
\hline & 1 & 2 & 3 & 4 & 5 & 6 & 7 & 8 & 9 \\
\hline $\ln ($ value added $)-5$ & $\begin{array}{c}0.703 * * \\
(6.62)\end{array}$ & $\begin{array}{c}0.417 * * \\
(3.18)\end{array}$ & $\begin{array}{l}0.500 * * \\
(2.99)\end{array}$ & $\begin{array}{l}0.128 \\
(0.05)\end{array}$ & $\begin{array}{l}13.15 * * \\
(3.14)\end{array}$ & $\begin{array}{c}18.88 * * \\
(3.90)\end{array}$ & $\begin{array}{l}0.299 \\
(0.51)\end{array}$ & $\begin{array}{c}1.798 * * \\
(3.46)\end{array}$ & $\begin{array}{c}1.735 * * \\
(3.44)\end{array}$ \\
\hline $\ln (\text { value added })_{-5}$ & 0.150 & -0.022 & 0.038 & $8.617 * *$ & 3.934 & 2.933 & 0.669 & 0.436 & 0.812 \\
\hline$\times$ Second period dummy & $(1.43)$ & $(-0.21)$ & $(0.23)$ & $(2.78)$ & $(1.19)$ & $(0.60)$ & $(1.14)$ & $(1.06)$ & $(1.61)$ \\
\hline $\begin{array}{l}\text { New marketing } \\
\text { channel share }-5\end{array}$ & $\begin{array}{l}0.018 * * \\
(3.52)\end{array}$ & $\begin{array}{l}0.014 * \\
(2.24)\end{array}$ & $\begin{array}{l}0.011 \\
(1.33)\end{array}$ & $\begin{array}{c}0.615 * * \\
(4.93)\end{array}$ & $\begin{array}{l}-0.476 * \\
(-2.33)\end{array}$ & $\begin{array}{l}-0.397 \\
(-1.64)\end{array}$ & $\begin{array}{l}0.031 \\
(1.11)\end{array}$ & $\begin{array}{l}0.009 \\
(0.36)\end{array}$ & $\begin{array}{l}-0.013 \\
(-0.52)\end{array}$ \\
\hline Profit margin -5 & $\begin{array}{c}-0.026 * * \\
(-2.99)\end{array}$ & $\begin{array}{l}-0.014 \\
(-1.50)\end{array}$ & $\begin{array}{l}-0.015 \\
(-1.31)\end{array}$ & $\begin{array}{l}-0.058 \\
(-0.25)\end{array}$ & $\begin{array}{l}-0.599 * \\
(-1.93)\end{array}$ & $\begin{array}{l}-0.698 * \\
(-2.09)\end{array}$ & $\begin{array}{c}0.079 * \\
(1.66)\end{array}$ & $\begin{array}{l}-0.090 * \\
(-2.35)\end{array}$ & $\begin{array}{l}-0.051 \\
(-1.46)\end{array}$ \\
\hline $\begin{array}{l}\text { Profit margin }-5 \\
\times \text { Second period dummy }\end{array}$ & $\begin{array}{l}-0.040 * * \\
(-2.71)\end{array}$ & $\begin{array}{c}-0.059 * * \\
(-3.67)\end{array}$ & $\begin{array}{c}-0.072 * * \\
(-3.48)\end{array}$ & $\begin{array}{l}-0.726^{*} \\
(-1.76)\end{array}$ & $\begin{array}{c}-1.403 * * \\
(-2.72)\end{array}$ & $\begin{array}{l}-0.795 \\
(-1.32)\end{array}$ & $\begin{array}{c}-0.591 * * \\
(-7.14)\end{array}$ & $\begin{array}{l}-1.051 * * \\
(-16.44)\end{array}$ & $\begin{array}{l}-1.141 * * \\
(-18.25)\end{array}$ \\
\hline $\begin{array}{l}\text { Employment of } \\
\text { engineers }-5\end{array}$ & $\begin{array}{l}0.108 * * \\
(2.81)\end{array}$ & $\begin{array}{l}0.030 \\
(0.64)\end{array}$ & $\begin{array}{l}0.043 \\
(0.79)\end{array}$ & $\begin{array}{l}3.287 * * \\
(3.23)\end{array}$ & $\begin{array}{l}-2.157 \\
(-1.43)\end{array}$ & $\begin{array}{l}-1.935 \\
(-1.23)\end{array}$ & $\begin{array}{l}0.448 * \\
(2.10)\end{array}$ & $\begin{array}{l}-0.008 \\
(-0.05)\end{array}$ & $\begin{array}{l}0.038 \\
(0.23)\end{array}$ \\
\hline $\begin{array}{l}\text { Engineer employment }-5 \\
\times \text { Second period dummy }\end{array}$ & $\begin{array}{l}-0.079 * \\
(-1.86)\end{array}$ & $\begin{array}{l}0.041 \\
(0.73)\end{array}$ & $\begin{array}{l}0.045 \\
(0.64)\end{array}$ & $\begin{array}{c}-3.339 * * \\
(-2.89)\end{array}$ & $\begin{array}{l}-0.297 \\
(-0.17)\end{array}$ & $\begin{array}{l}-2.329 \\
(-1.13)\end{array}$ & $\begin{array}{l}-0.306 \\
(-1.29)\end{array}$ & $\begin{array}{l}0.216 \\
(0.98)\end{array}$ & $\begin{array}{l}0.292 \\
(1.37)\end{array}$ \\
\hline Second period dummy & $\begin{array}{l}0.292 \\
(0.60)\end{array}$ & $\begin{array}{c}1.635^{* *} \\
(3.27)\end{array}$ & $\begin{array}{l}1.380 \\
(1.66)\end{array}$ & $\begin{array}{l}-22.03 \\
(-1.56)\end{array}$ & $\begin{array}{l}4.781 \\
(0.30)\end{array}$ & $\begin{array}{l}38.33 \\
(1.59)\end{array}$ & $\begin{array}{l}4.874 * \\
(1.81)\end{array}$ & $\begin{array}{c}10.60 * * \\
(5.34)\end{array}$ & $\begin{array}{l}9.327 * * \\
(3.72)\end{array}$ \\
\hline Constant & $\begin{array}{c}2.257 * * \\
(6.02)\end{array}$ & $\begin{array}{c}3.604 * * \\
(7.39)\end{array}$ & $\begin{array}{l}3.581 * * \\
(5.14)\end{array}$ & $\begin{array}{l}8.218 \\
(0.73) \\
\end{array}$ & $\begin{array}{l}-25.60 \\
(-1.64)\end{array}$ & $\begin{array}{c}-51.07 * * \\
(-2.53)\end{array}$ & $\begin{array}{l}11.04 * * \\
(4.65)\end{array}$ & $\begin{array}{l}7.848 * * \\
(4.06)\end{array}$ & $\begin{array}{c}6.832 * * \\
(3.25)\end{array}$ \\
\hline$R$-squared & 0.77 & 0.83 & 0.85 & 0.20 & 0.53 & 0.68 & 0.74 & 0.88 & 0.93 \\
\hline $\begin{array}{l}p \text {-value for } \mathrm{F} \text { test that all } \\
\text { enterprise effect }=0\end{array}$ & & 0.00 & 0.00 & & 0.02 & 0.01 & & 0.00 & 0.00 \\
\hline Number of enterprises & 95 & 95 & 62 & 95 & 95 & 62 & 95 & 95 & 62 \\
\hline Number of observations & 150 & 150 & 100 & 150 & 150 & 100 & 150 & 150 & 100 \\
\hline
\end{tabular}

\section{Notes:}

(i) Numbers in parentheses are $t$-statistics.

(ii) The symbol * and ** indicate statistical significance at the $5 \%$ and $1 \%$ levels, respectively, for a one-sided test. 


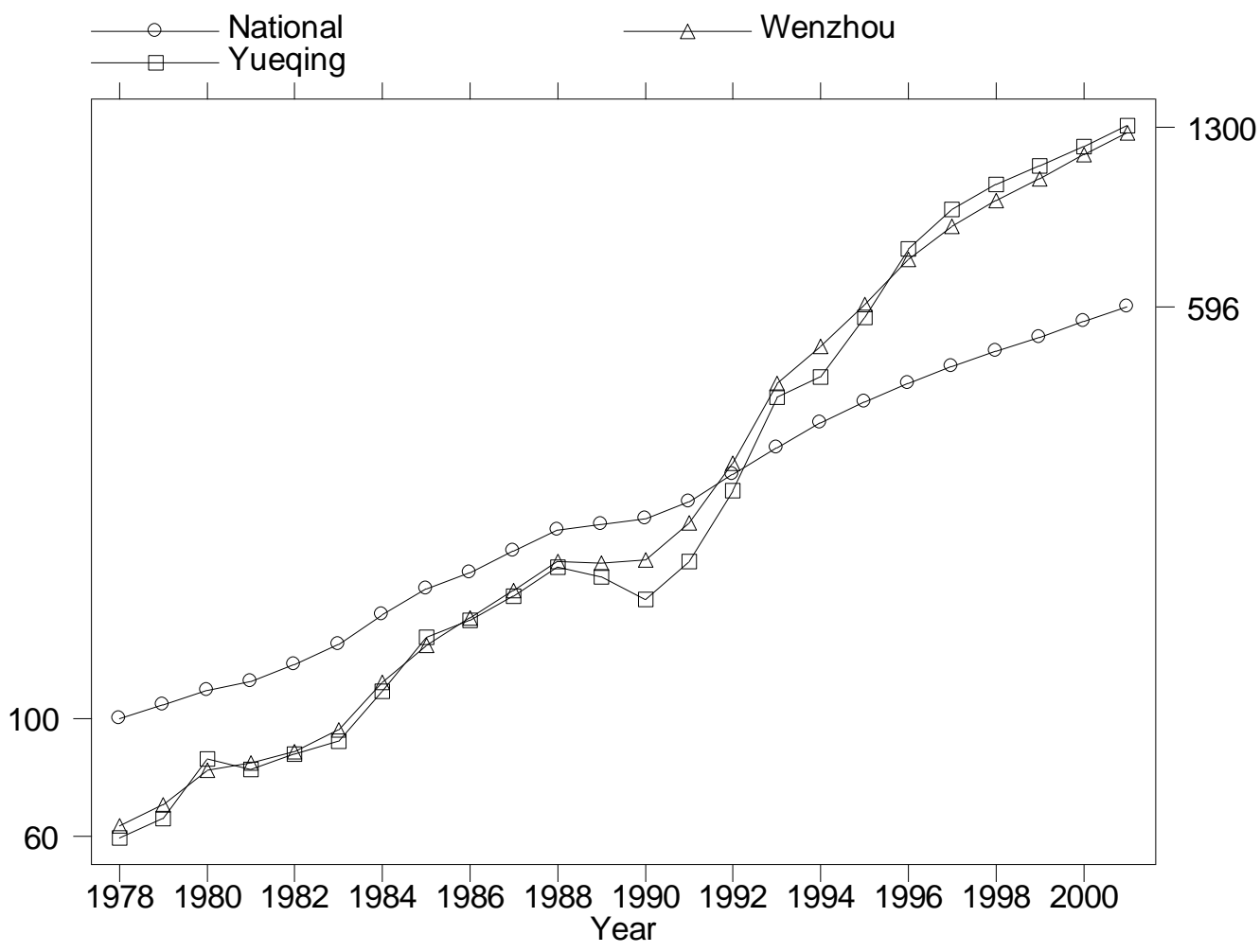

FIG. 1.

Index of Real GDP per Capita in the Yueqing Cluster, Wenzhou City, and China, 1978 to 2001 (China in 1978=100)

Sources: China Statistical Yearbook 2002 (State Statistical Bureau, 2002), Comprehensive Statistical Data and Materials on 50 Years of New Zhejiang (Statistical Bureau of Zhejiang Province, 2000), and Zhejiang Statistical Yearbook (Statistical Bureau of Zhejiang Province, 2000, 2001, and 2002). 


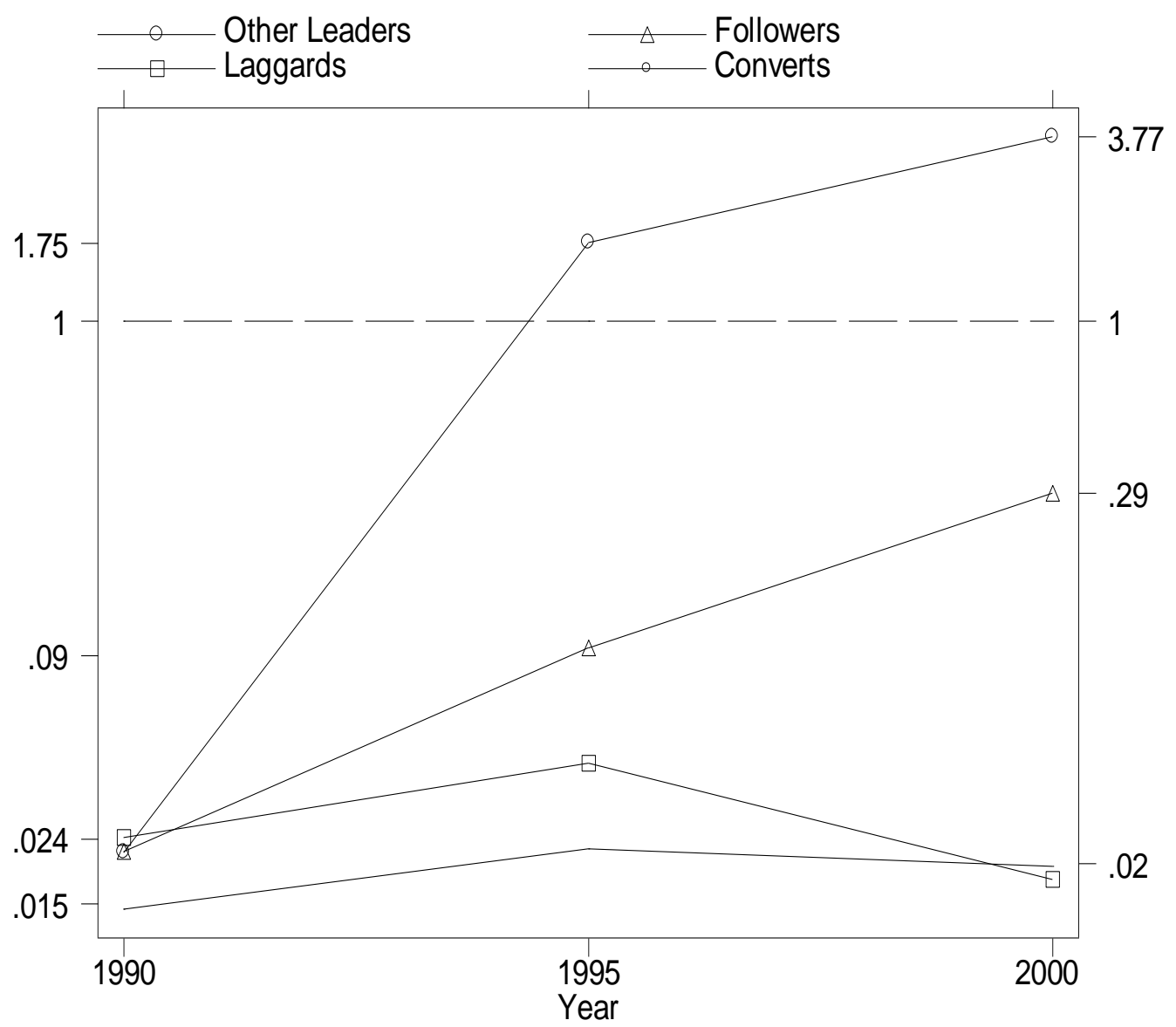

FIG. 2.

Average Value Added by Enterprise Type

Relative to the Innovator

Note: For enterprises with subsidiaries, the total value added of the enterprise group is considered. 